HEALING ARTS

Materia Medica

\title{
The World is Taking Back What it Let Me Have
}

\author{
Paul Rousseau, MD
}

Medical University of South Carolina, Mount Pleasant, SC, USA.

Childhood was when tomorrows were forever, and time so distant, horizons were imaginary.

Yesterdays were novels of a thousand pages, with happy endings tinged by an occasional skinned knee. And todays lingered forever, the minutes like hours, and hours like days,

sun forever in the sky, night arriving only after hide'n'seek, bike rides,

and running to the call of dinner.

Then, in the twilight before sleep, chapters of the day were revisited,

ready to find their places in the pages of a neoteric yesterday, before the coming of morning

when another story would unfold anew.

But now, some 60 plus years on,

the nights are often sleepless, disturbed by the uncertainties of being,

with wrinkles scratched out of skin leathered by the bleached sun,

the same sun that long ago was forever in the sky.

The tomorrows come so quickly, while the todays slip away so easily.

Yesterdays are the only solid ground, and they seem garbled by age.
So it's no surprise that life seems so uneven, since nothing stays, and time continues to unspool. It's like broken pieces glued together, one piece always missing, never found, and never to be found.

And regrets, they can be haunting - but we all have them. Part of being human and part of love.

But mine seem never-ending, wrapped in heartache and loss, for 8 years past, four entered a hospital and three came home.

Corresponding Author: Paul Rousseau, MD, Medical University of South Carolina, Mount Pleasant, SC 29464, USA (email: palliativedoctor@aol.com).

J Gen Intern Med 30(5):697

DOI: $10.1007 / \mathrm{s} 11606-014-3118-0$

Published online December 20, 2014

(c) Society of General Internal Medicine 2014 